\title{
The Federal Constitution: Is Malaysia a Secular State?
}

\author{
Mohamed Azam Mohamed Adil *
}

\section{Introduction}

The discussion on whether Malaysia is an Islamic or secular state has been a much hotly debated topic recently. In the government's written answer to a question raised by Oscar Ling Chai Yew (DAP-Sibu) at Dewan Rakyat on 16 June 2014, Jamil Khir, Minister in the Prime Minister's Department re-asserted that Malaysia is an Islamic state. This view was supported by Tun Mahathir Mohamad arguing that in an Islamic state like Malaysia, justice applies to all, Muslims and non-Muslims alike. This was re-affirmed by Amin Mulia, the Dewan Rakyat's Speaker that Malaysia is an Islamic state simply because Islam is the only religion stated in the Federal Constitution. Unlike Turkey and India where the word "secular" is clearly provided in their respective Constitutions, such provision is not found in the Federal Constitution.

Notwithstanding the above, the relevant White Paper signifies that the country was meant to be a secular state. In the early stage of the drafting of the Constitution, the Reid Commission had proposed inserting a provision stating the country is a secular state. However, in the final stage, they agreed to accept a provision that made Islam the official religion of the Federation, but it shall not impose any disability on non-Muslim nationals professing and practising their own religions and shall not imply that the State is not a secular State.

Furthermore, the historians have suggested that Malaya was an Islamic state. Islamic laws were in practice which included criminal and civil laws. The most common Islamic laws notably are Hukum Kanun Melaka, Undang-undang Pahang, Undang-undang Johor, Undang-undang Perak, and others. However, when the British colonised Malaya, all these laws were gradually changed to English laws through courts' judgements where English judges preferred to refer to the English laws. The other way was through the introduction of English laws like the Contract Act, Penal Code, Criminal Procedure Code and others into the mainstream.

Ironically, when Malaya gained independence on 31 August 1957, the words Islamic state were not incorporated into the Constitution. Nor is the word "secular" found in the Federal Constitution. It was only on 29 September 2001, after 44 years of independence, during his tenure as Prime Minister, Mahathir Mohamad made a declaration that Malaysia was as Islamic state. This announcement was not followed by any amendment to the Federal Constitution. In his book 
entitled Malaysia Adalah Sebuah Negara Islam (Malaysia is an Islamic State) Wan Zahidi Wan Teh argues that "Malaysia has fulfilled the requirements of an Islamic State". According to him, a reference must be made to the opinion of Muslim scholars about the definition of an Islamic state. Firstly, the nation has to be under Muslim governance, its defence in the hands of Muslims, and it must be the responsibility of every Muslim to defend it. Secondly, the nation is controlled by Muslims and managed peacefully. Thirdly, the laws of an Islamic ruler are enforced, and finally, Islamic law is adhered to.

\section{The Position of Islam in the Federal Constitution}

Article 3(1) appears, to some extent, to reiterate the rights protected under Article 11(1) and also reaffirms the supremacy of Islam under the Federal Constitution. Furthermore, Islam is placed above other religions in the Federation, yet in Che Omar bin Che Soh v Public Prosecutor [1988] 2 MLJ 55, the Supreme Court (now the Federal Court) held that "although there can be no doubt that Islam is not just a mere collection of dogmas and rituals but it is a complete way of life covering all fields of human activities, may they be private or public, legal, political, economic, social, cultural, moral or judicial", the provision of Article 3(1) merely provided for a ritualistic and ceremonial role of Islam. Sheridan also seems to agree with the Che Omar decision. He posits that Article 3(1) does not mean anything except that it imposes an obligation on the participants in any federal ceremonial to regulate any religious parts of the ceremony according to Muslim rites. However, according to Abdul Aziz Bari, this case does not elaborate clearly the position of Islam as stated in the Reid's Commission Report and the White Paper. Thus, he argues that the Che Omar decision merely ruled that Article 3(1) should not become the basis to challenge the legality of statutes. In other words, it merely limits the operation of Islam as stated in the provision. It must also be noted that the extent and implementation of Islam in the Constitution should not be assessed or interpreted solely from the context or point of view of Article 3(1). But, it is also contended that the Che Omar decision merely differentiated the position of Islamic law as prescribed by Article 3(1) of the Federal Constitution. It was argued by the appellant since Islam is the religion of the Federation, and since the Constitution is the supreme law of the Federation, the imposition of the death penalty upon drug traffickers, not being an Islamic law per se and not in accordance with hudud or qisas laws, is contrary to Islamic injunctions and is therefore unconstitutional. The Supreme Court (now the Federal Court) rejected this argument, saying that provision in Article 3(1) does not actually give a meaning that Malaysia is an Islamic state, where in reality Islamic law only applies to Muslims merely in matters of personal laws. And since the Constitution 
makes a clear distinction between private law and public law, offences like drug trafficking are under the Federal List, and therefore constitutional.

A wider interpretation on the position of Islam is thus necessary. Islam seems to be placed above other religions in the Federation. In Meor Atiqulrahman bin Ishak \& Anor. v Fatimah Bte Sihi \& Anor, [2000] 5 MLJ 382, the learned judge, Dato' Mohd Noor Abdullah interpreted Article 3(1) that states "Islam is the religion of the Federation but other religions may be practiced in peace and harmony in any part of the Federation" which means that Islam is the supreme religion and its position is not in par with other religions such as Christianity, Buddhism, Hinduism and others.

Perhaps the position taken by Shad Faruqi, Aziz Bari, Lee Min Choon and Hassan Bahrom that categorised Malaysia somewhere between the secular state and the Islamic state, could be the answer to the ambiguity of the position of Islam in Malaysia. Thus, according to Shad Faruqi, "Malaysia is neither a full-fledged Islamic state nor wholly secular" but that "in view of the fact that Muslims constitute the majority population, and Islamisation is being vigorously enforced, Malaysia can indeed be described as an Islamic or Muslim state". In addition, Shad Faruqi adds that "in a secular constitution, there is no prescribed official religion and no state aid is given to any religion or for any religious activities, but the word religion does occur at least twenty four times in the Federal Constitution". It must be emphasised that despite the Islamisation policy that has taken place for some three decades, there was no attempt by the present government to amend the Federal Constitution to declare Malaysia an Islamic state.

The other important point taken from Article 37 (reading with the Fourth Schedule) of the Federal Constitution is that the King upon taking the oath of office must truly declare that He will at all times protect the religion of Islam.

Despite the fact that the Federal Constitution does not provide a clear provision to advocate that Malaysia is an Islamic state, there are significant provisions such as Articles 3(1) and 12(2) in the Constitution that signify the religion of Islam is given a special position in the Federation. We may conclude that Malaysia is not a secular state, nor is it a truly theocratic state.

\section{Notes}

* Mohamed Azam Mohamed Adil is Associate Professor and Deputy CEO, International Institute of Advanced Islamic Studies (IAIS) Malaysia (Email: mazamadil@iais.org.my). 